Nig. J. Biotech. Vol. 35 (2018) 25-33

ISSN: 01891731

Available online at http://www.ajol.info/index.php/njb/index

and www.biotechsocietynigeria.org

DOI: https://dx.doi.org/10.4314/njb.v35i1.4

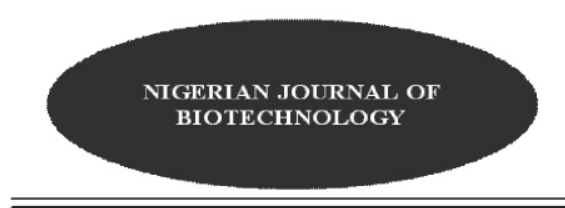

\title{
Optimization of Biodiesel Production from Spent Cooking Oil by Fungal Lipase Using Response Surface Methodology
}

Kareem, S. 0. ${ }^{1}$, Adio, O. Q. ${ }^{1}$, Osho, M. B. ${ }^{2}$, Banjo, T. T. ${ }^{3}$ and Omeike, S. 0. ${ }^{1}$

\begin{abstract}
${ }^{1}$ Department of Microbiology, Federal University of Agriculture, Abeokuta, P.M.B. 2240, Ogun State, Nigeria.
\end{abstract}
${ }^{2}$ Department of Biological Sciences, McPherson University, Seriki-Sotayo, Ogun State, Nigeria.

${ }^{3}$ Department of Biological Sciences, Wellspring University, PMB 1230, Irhirhi road, Benin city, Edo state, Nigeria.

Copyright resides with the authors in terms of the Creative Commons License 4.0.
(See http://creativecommons.org/licenses/by/4.0/).
Condition of use: The user may copy, distribute, transmit and adapt the work, but must recognize
the authors and the Nigerian Journal of Biotechnology.

Abstract

This study evaluated the potential of optimizing Spent Cooking Oil (SCO) transesterification for biodiesel production using Response Surface Methodology (RSM). Potential biodiesel yield from transesterification was optimized using a three-level four factor Response Surface Central Composite Design (RSCCD) with methanol oil ratio (1:1 to $3: 1$ ), temperature range $35-45{ }^{\circ} \mathrm{C}$, agitation speed range $100-200 \mathrm{rpm}$ and enzyme load 10-20\%. Biodiesel properties including fatty acid methyl ester (FAME), Flash Point (FP), Pour Point (PP) and kinematic viscosity were compared with American (ASTM D6751) and European Union (EN 14214) standards. Biodiesel production was optimum at 3:1 methanol to oil ratio, temperature of $35{ }^{\circ} \mathrm{C}$, agitation speed of $150 \mathrm{rpm}$ and $20 \%$ enzyme load. 9-octadecanoic acid-hydroxyl methyl ester $(33.83 \%)$ was the prominent FAME produced, while the viscosity $\left(6 \mathrm{~mm}^{2} / \mathrm{s}\right)$, density $\left(893 \mathrm{~kg} / \mathrm{m}^{3}\right), \mathrm{FP}\left(260^{\circ} \mathrm{C}\right)$ and PP ($0.5^{\circ} \mathrm{C}$ ) all met both American and European standards. This study showed that RSM is a viable methodology which could be used for optimization of biodiesel production from biological sources.

Keywords: Biodiesel; Spent cooking oil; FAME; Response Surface Methodology (RSM); Central Composite Design

\section{Introduction}

Vast depletion of non-renewable energy sources has led to the search for alternative energy sources (Owusu and Asumadu-Sarkodie, 2016). Price hike in petroleum-based products as well as greenhouse gas emissions contribute significantly the need to search for alternative and renewable energy sources (Abbasi et al., 2011; Ribeiro et al., 2011).

Biodiesel is a non-toxic, non-sulphur containing renewable energy fuel consisting of long chain fatty acid derived from vegetable oils or animal fats (Vincente et al., 2007). Enzymatic conversion of oils to biodiesel by lipases as biocatalysts is receiving much interest in biodiesel production due to its high efficiency and production of a highly purified product
(Dermibas, 2003; Akoh, 2007). Oils from various feed stock are used for the enzymatic production of biodiesel, with vegetable oil currently being used worldwide as a sustainable commercial feedstock (Dermibas, 2006). The use of vegetable oil and other edible oils sourced from feedstock such as sunflower, soyabeans, rapeseed, corn among others in biodiesel production is of great concern to food security due to competition. Since the prices of edible vegetable oils, e.g. soybean oil, are higher than that of diesel fuel, waste vegetable like palm, sunflower, and algal oils (Encinar, 1999; Hossain 2009b) and non-edible crude vegetable oils have been intensively investigated as potential low priced biodiesel sources. Biodiesel made from this feedstock could be more economical than 
the biodiesel produced from refined vegetable oil. The waste oil product can be of advantage as they have a higher proportion of saturated fatty acids (Hossain, 2009a). Waste cooking oil is a good feedstock to produce biodiesel for waste management and recycling process (Sarin, 2007). Moreover, waste cooking oil can be used as an alternative source of fuel because it is cheap and readily available.

Response surface methodology (RSM), on the other hand, is a statistical tool which is used by scientists to optimize processes; example includes fermentation processes (Zhang et al., 2000). The RSM is equipped with statistical tools to determine the significance of a factor over a response. The evaluation of factors using the RSM uses experimental design in order to distribute the selected variables within the boundaries of the design.

Hence, the aim of this study was to optimize fatty acid methyl esters (FAME) production from spent cooking oils by lipase of Aspergillus niger using Response Surface Methodology.

\section{Materials and Methods}

Materials

Spent cooking oil (SCO) was collected locally from homes and restaurants. Raw materials for the composition of culture media such as rice bran, Palm Kernel Cake (PKC), Groundnut Cake (GNC), starch and Olive oil were purchased locally in Abeokuta, Ogun State, and sterilized accordingly prior to use. All chemicals including methanol, ethanol, Tween 80, bromcresol green, lactophenol blue, sodium diodoethyl sulphate, chloroform, gum arabic, Thymolphtalein, Bovine serum Albumin (BSA), sodium hydroxide, sodium dihydrogen phosphate, monosodium hydrogen phosphate, Sodium potassium tartarate, Copper sulphate pentahydrate, and Potassium iodide were of analytical grade.

\section{Microorganism}

Aspergillus niger F7-02, is a lipase-producing fungus used for transesterification from a previous study (Adio et al., 2015). It was stored at $4^{\circ} \mathrm{C}$ and sub-cultured bimonthly on a SDA. Prior to its use in this study, retention of lipolytic activity was confirmed according to Akpan (2004). SDA medium was modified with bromocresol green $(0.1 \%)$ and Tween $80(1 \%)$. Strain F7-02 was inoculated and medium incubated for $72 \mathrm{~h}$ at $30^{\circ} \mathrm{C}$. Lipase production was confirmed by colour change around the colonies.

\section{Lipase production by Solid State Fermentation}

For lipase production, Aspergillus niger F7-02 was grown via solid-state fermentation on a modified compounded medium described by Osho et al. (2014). The compounded medium substrates included rice bran, palm kernel cake waste, groundnut cake waste, and starch flour in the ratio 5:5:3:1 (\% w/w), and moistened with $55 \%$ water. Inoculated medium was incubated at $30^{\circ} \mathrm{C}$ for $72 \mathrm{~h}$. Moldy medium was dissolved in $50 \mathrm{mM}$ sodium phosphate buffer $\mathrm{pH} 8(1: 10 \mathrm{w} / \mathrm{v})$ and the mixture incubated at $4^{\circ} \mathrm{C}$ for $3 \mathrm{~h}$ with intermittent shaking. The filtered extract served as the crude enzyme source.

\section{Assay of Lipase Activity}

Lipase activity was determined according to combined methods of Praphan and Kirk (2001) and Janaina et al. (2006). Olive oil substrate emulsion was prepared by mixing $25 \mathrm{~mL}$ of olive oil with $7 \%$ arabic gum solution $(75 \mathrm{~mL})$ in a conical flask and incubate at $37^{\circ} \mathrm{C}$ for 15 minutes in a water bath (Nickel Electro Ltd, England). Reaction mixture was made up of $50 \mathrm{ml}$ olive oil emulsion and $10 \mathrm{ml}$ crude enzyme incubated at $50^{\circ} \mathrm{C}$ for 30 minutes with intermittent shaking in water bath. At 5-minute intervals, $5 \mathrm{~mL}$ of reaction mixture was removed and mixed with 5 $\mathrm{mL}$ ethanol (95\%) and thymolphtalein indicator (2-3 drops) in a conical flask to stop the reaction. The released fatty acid was titrated with sodium hydroxide $(0.05 \mathrm{~N})$ in a burette until a light blue color appears.

The quantity of fatty acid liberated is equivalent to the volume of $\mathrm{NaOH}$ used and it was calculated using equation (1), where $\mathrm{N}$ is the normality of $\mathrm{NaOH}$ used.

Umole fatty acid per $\mathrm{ml}$ sample $=$

((mI NaOH of sample $-\mathrm{ml} \mathrm{NaOH}$ of blank) $\times \mathrm{N} \times 1000)$

(1)

One unit (U) of lipase activity is defined as the amount of enzyme that releases from the emulsion substrate 1 umole of fatty acid per $\mathrm{ml}$ per minute under specific assay condition. 
Enzymatic production of biodiesel by lipase of Aspergillus niger

Biodiesel production was carried out as described by Taufiq-Yap et al. (2011). SCO (30 g w/v) was heated to $40^{\circ} \mathrm{C}$ in $250 \mathrm{ml}$ Erlenmeyer flasks, crude lipase enzyme ( $10 \% \mathrm{v} / \mathrm{w}$ of oil) was added and mixture was incubated in a shaker incubator for 24 hours at $40^{\circ} \mathrm{C}$ and $150 \mathrm{rpm}$. Thereafter, methanol was added to the mixture and reaction proceeded for a further $24 \mathrm{~h}$. Reaction products were separated into fractions by sedimentation and biodiesel was separated from glycerol and other impurities in separating funnel.

\section{Optimization of biodiesel production}

Biodiesel production factors considered included temperature of reaction $\left(35-45^{\circ} \mathrm{C}\right)$, methanol-to-SCO molar ratio (1-3, with the SCO fixed at 1) and enzyme load (10-20\%) and agitation (100-200 rpm). Transesterification of SCO proceeded using the three-level-four-factor Response Surface Central Composite Design (RSCCD) of Design-Expert software version 7b1.1. Thirty (30) experimental runs were generated using the combination of factors at different levels (low, mid and high; $-1,0,+1$ ) and the randomized experiments were carried out simultaneously as previously described. Transesterification product for each experimental run was allowed to settle for $24 \mathrm{~h}$ in a separating funnel, and the fatty acid methyl ester (FAME) called the biodiesel, was separated from the glycerol layer. Biodiesel yield (\% wt.), which is relative to the amount of SCO was calculated according to the method of Fan et al. (2011) as described in equation 2:
Statistical analysis of the biodiesel yield from lipase treated SCO

Responses obtained from three-factorial experimental runs were analyzed by ANOVA for response surface linear model and the effect of factors considered singly and in combination was determined. The prediction model was also used to predict possible optimum yield.

\section{Characterization of biodiesel}

Properties of biodiesel produced (FAME) was analyzed via Gas Chromatography (Agilent Technologies 7890A model) according to Atabani et al. (2012). These properties included Pour Point (PP), Flash Point (FC), Cloud Point (CP) and kinematic viscosity. Density of crude transesterified biodiesel at $15{ }^{\circ} \mathrm{C}$ was also determined, and all properties compared with both American Standard (ASTM 6751-3) and European Union Standard (EN 14214) in properties and quality of biodiesel. Biodiesel properties were analyzed in triplicate.

\section{Results and Discussion}

The optimization of biodiesel production from spent cooking oil using a three-level four factor Response Surface Central Composite Design (RSCCD) showed that maximum biodiesel yield of $97 \%$ was obtainable under three experimental runs. Experimental runs which produced highest biodiesel yield had factors temperature $\left(35^{\circ} \mathrm{C}\right)$ and molar ratio $(3: 1)$ at similar levels, while agitation and enzyme load were different. Similarly, minimum biodiesel yield of $92 \%$ was obtained at transesterification experiment which proceeded at temperature $45^{\circ} \mathrm{C}$ and of $1: 1$ molar ratio respectively (Table 1). 
Table 1: Experimental design and Response (Biodiesel yield) of different experimental runs response of different experimental runs

\begin{tabular}{|c|c|c|c|c|c|c|c|}
\hline Std. & Rum & Block & $\begin{array}{l}\text { Factor } 1 \\
\text { Temp. } \\
{ }^{\circ} \mathrm{C}\end{array}$ & $\begin{array}{l}\text { Factor } 2 \\
\text { Molar ratio } \\
\text { M }\end{array}$ & $\begin{array}{l}\text { Factor } 3 \\
\text { Agitation } \\
\text { (rpm) }\end{array}$ & $\begin{array}{c}\text { Factor } 4 \\
\text { Enzyme load } \\
(\%)\end{array}$ & $\begin{array}{c}\text { Response } 1 \\
\text { Yield } \\
(\%)\end{array}$ \\
\hline 23 & 1 & Block 1 & 40.00 & 2.00 & 150.00 & 7.93 & 94 \\
\hline 17 & 2 & Block 1 & 32.93 & 2.00 & 150.00 & 15.00 & 96 \\
\hline 8 & 3 & Block 1 & 45.00 & 3.00 & 200.00 & 10.00 & 94 \\
\hline 6 & 4 & Block 1 & 45.00 & 1.00 & 200.00 & 10.00 & 93 \\
\hline 3 & 5 & Block 1 & 35.00 & 3.00 & 100.00 & 10.00 & 97 \\
\hline 13 & 6 & Block 1 & 35.00 & 1.00 & 200.00 & 20.00 & 95 \\
\hline 20 & 7 & Block 1 & 40.00 & 3.41 & 150.00 & 15.00 & 95 \\
\hline 29 & 8 & Block 1 & 40.00 & 2.00 & 150.00 & 15.00 & 96 \\
\hline 14 & 9 & Block 1 & 45.00 & 1.00 & 200.00 & 20.00 & 93 \\
\hline 1 & 10 & Block 1 & 35.00 & 1.00 & 100.00 & 10.00 & 94 \\
\hline 22 & 11 & Block 1 & 40.00 & 2.00 & 220.71 & 15.00 & 96 \\
\hline 30 & 12 & Block 1 & 40.00 & 2.00 & 150.00 & 15.00 & 96 \\
\hline 4 & 13 & Block 1 & 45.00 & 1.00 & 100.00 & 10.00 & 92 \\
\hline 2 & 14 & Block 1 & 45.00 & 1.00 & 100.00 & 10.00 & 93 \\
\hline 21 & 15 & Block 1 & 40.00 & 2.00 & 79.29 & 15.00 & 95 \\
\hline 25 & 16 & Block 1 & 40.00 & 2.00 & 150.00 & 15.00 & 96 \\
\hline 10 & 17 & Block 1 & 45.00 & 1.00 & 100.00 & 20.00 & 93 \\
\hline 7 & 18 & Block 1 & 35.00 & 3.00 & 200.00 & 10.00 & 96.5 \\
\hline 16 & 19 & Block 1 & 45.00 & 3.00 & 200.00 & 20.00 & 94 \\
\hline 5 & 20 & Block 1 & 35.00 & 1.00 & 200.00 & 10.00 & 93 \\
\hline 27 & 21 & Block 1 & 40.00 & 2.00 & 150.00 & 15.00 & 96 \\
\hline 9 & 22 & Block 1 & 35.00 & 1.00 & 100.00 & 20.00 & 95 \\
\hline 12 & 23 & Block 1 & 45.00 & 3.00 & 100.00 & 20.00 & 96 \\
\hline 19 & 24 & Block 1 & 40.00 & 0.59 & 150.00 & 15.00 & 90 \\
\hline 11 & 25 & Block 1 & 35.00 & 3.00 & 100.00 & 20.00 & 97 \\
\hline 26 & 26 & Block 1 & 40.00 & 2.00 & 150.00 & 15.00 & 96 \\
\hline 18 & 27 & Block 1 & 47.07 & 2.00 & 150.00 & 15.00 & 93 \\
\hline 15 & 28 & Block 1 & 35.00 & 3.00 & 200.00 & 20.00 & 97 \\
\hline 28 & 29 & Block 1 & 40.00 & 2.00 & 150.00 & 15.00 & 96 \\
\hline 24 & 30 & Block 1 & 40.00 & 2.00 & 150.00 & 22.07 & 96 \\
\hline
\end{tabular}


The 3D Response surface plot of interactions at the different levels of factors is described in Figure 1. A curved response surface was obtained, with highest response at the upper left hand corner of the plot, corresponding to $35^{\circ} \mathrm{C}$ temperature and 3:1 molar ratio. Furthermore, effect of temperature and enzyme load on SCO biodiesel yield was described in response surface plots (Figure 2). It was observed that transesterification proceeding at $20 \%$ enzyme load and temperature of $35^{\circ} \mathrm{C}$ were conditions required for optimum biodiesel yields of $96.34 \%$ from SCO. The effects of molar ratio and enzyme load on biodiesel yield from SCO are described in Figure 3. Figure 4 shows a cube-plot which described the prediction model for SCO biodiesel optimization. Maximum biodiesel yield of $97.42 \%$ was predicted at molar ratio (3:1), $20 \%$ enzyme load and temperature of $35^{\circ} \mathrm{C}$, while minimum yield of $93.20 \%$ was predicted to occur at molar ratio (1:1) and enzyme load $10 \%$. Optimization parameters are in agreement with the report of Taufiq-Yap et al. (2011) who reported that stoichiometric ratio for transesterification requires 3 moles of methanol and 1 mole of oil to yield 3 moles of biodiesel and a mole of glycerol, which indicates that excess methanol, is required to drive the reaction towards the product, with enzyme load also a vital factor. Similar observation was reported by Nadir et al., (2009), and was attributed to the fact that excess enzyme can make oils viscous, causing problem of mixing and demanding higher power consumption for adequate stirring (Kim et al., 2004; Xie and Li, 2006).

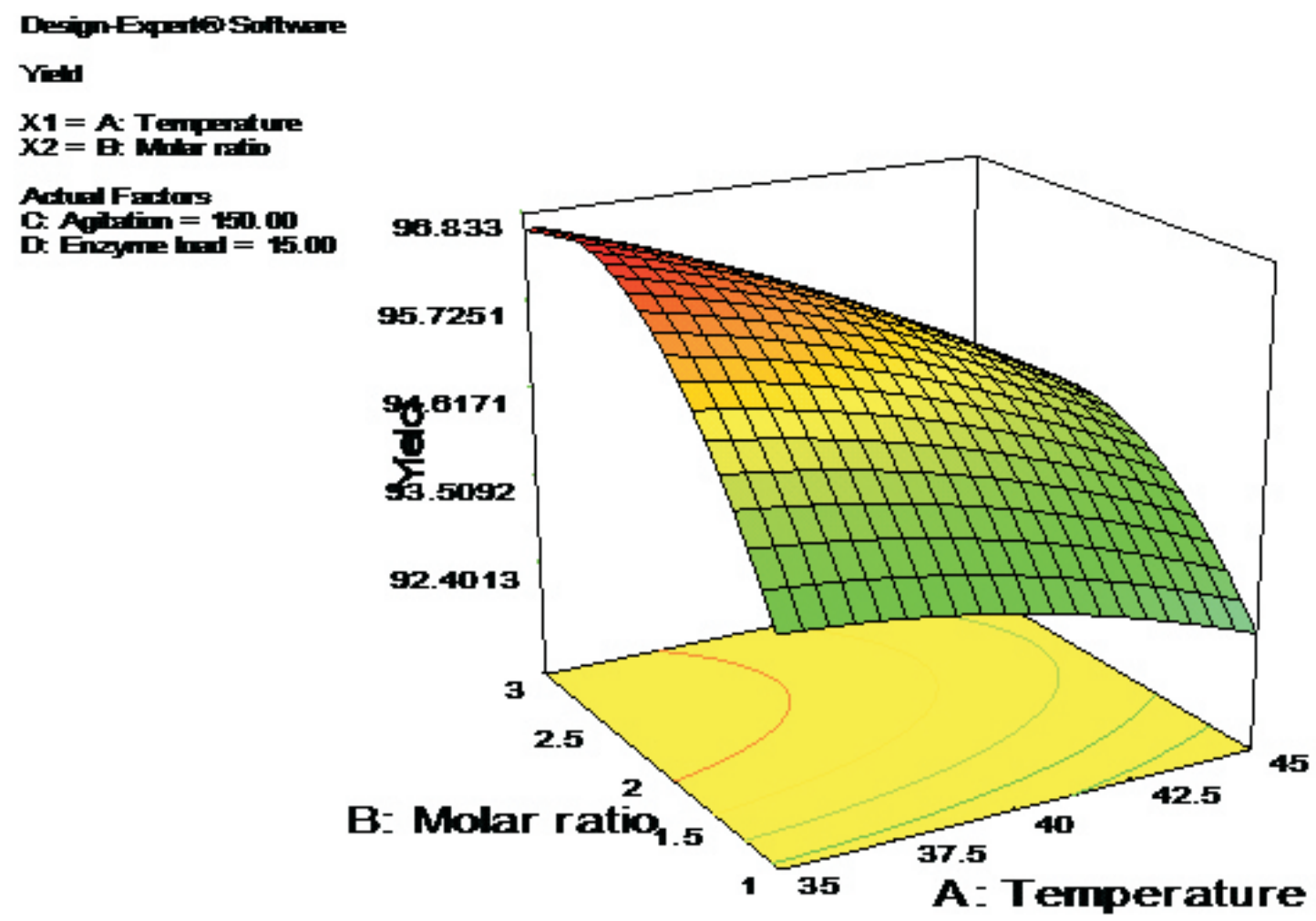

Fig 1: Effect of temperature and molar ratio on biodiesel yield 
Des ign -E xperte $S$ of tw ar

$Y$ ield

$\mathrm{X} 1=\mathrm{A}:$ T em perature

$X 2$ = D: Enzyme lo ad

A ctual F actors

B: Molar ratio $=2.00$
C: A A itation $=150.00$

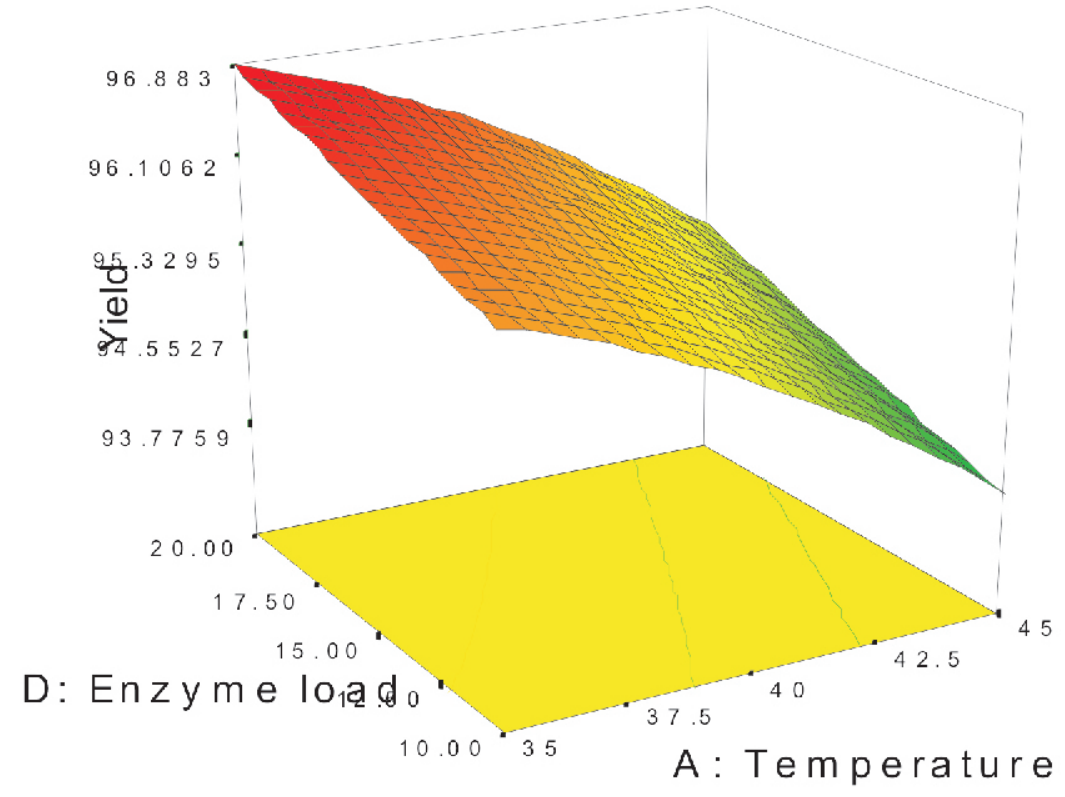

Fig 2: Effect of temperature and enzyme load on biodiesel yield

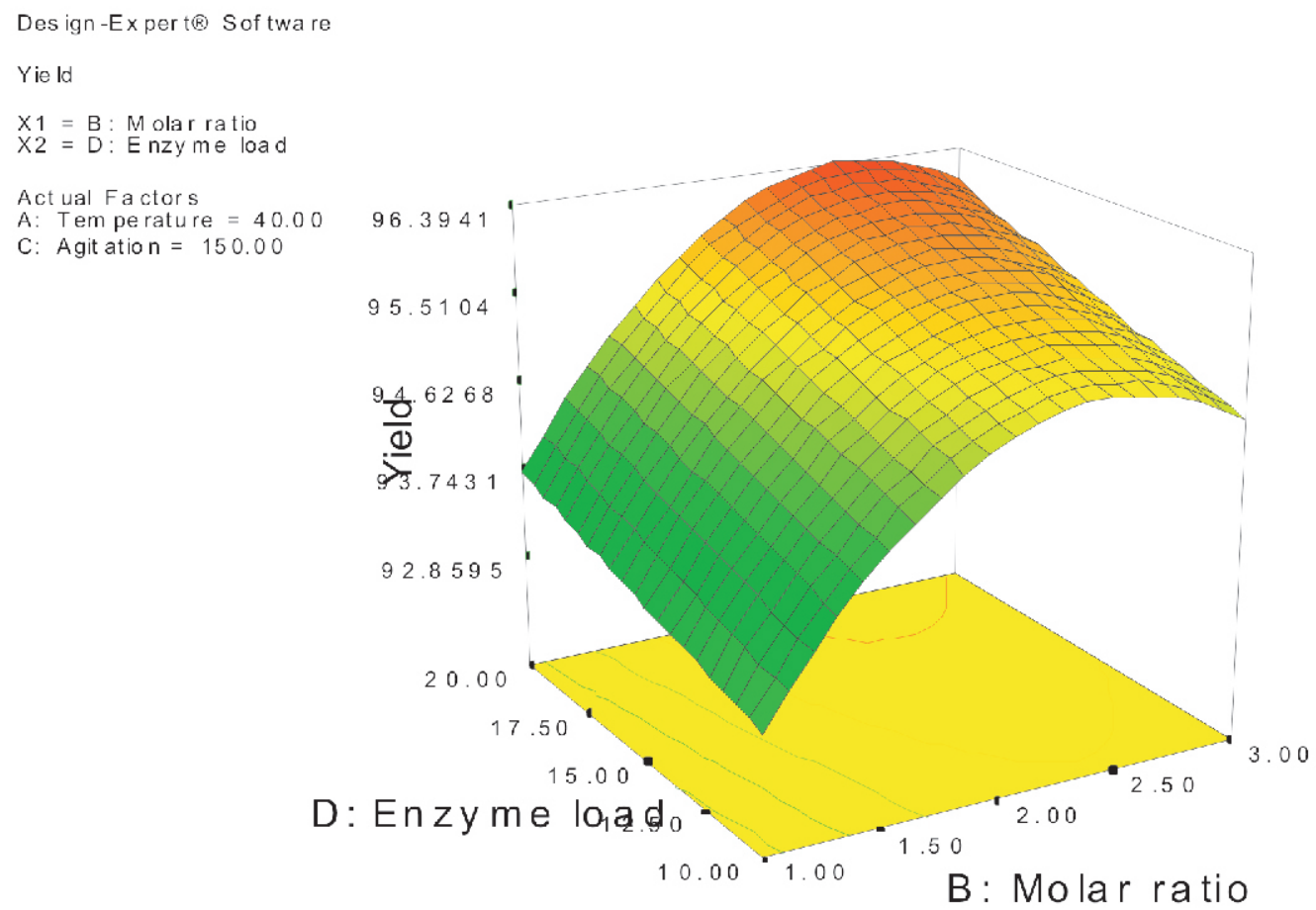

Fig 3: Effect of molar ratio and enzyme load on biodiesel yield 

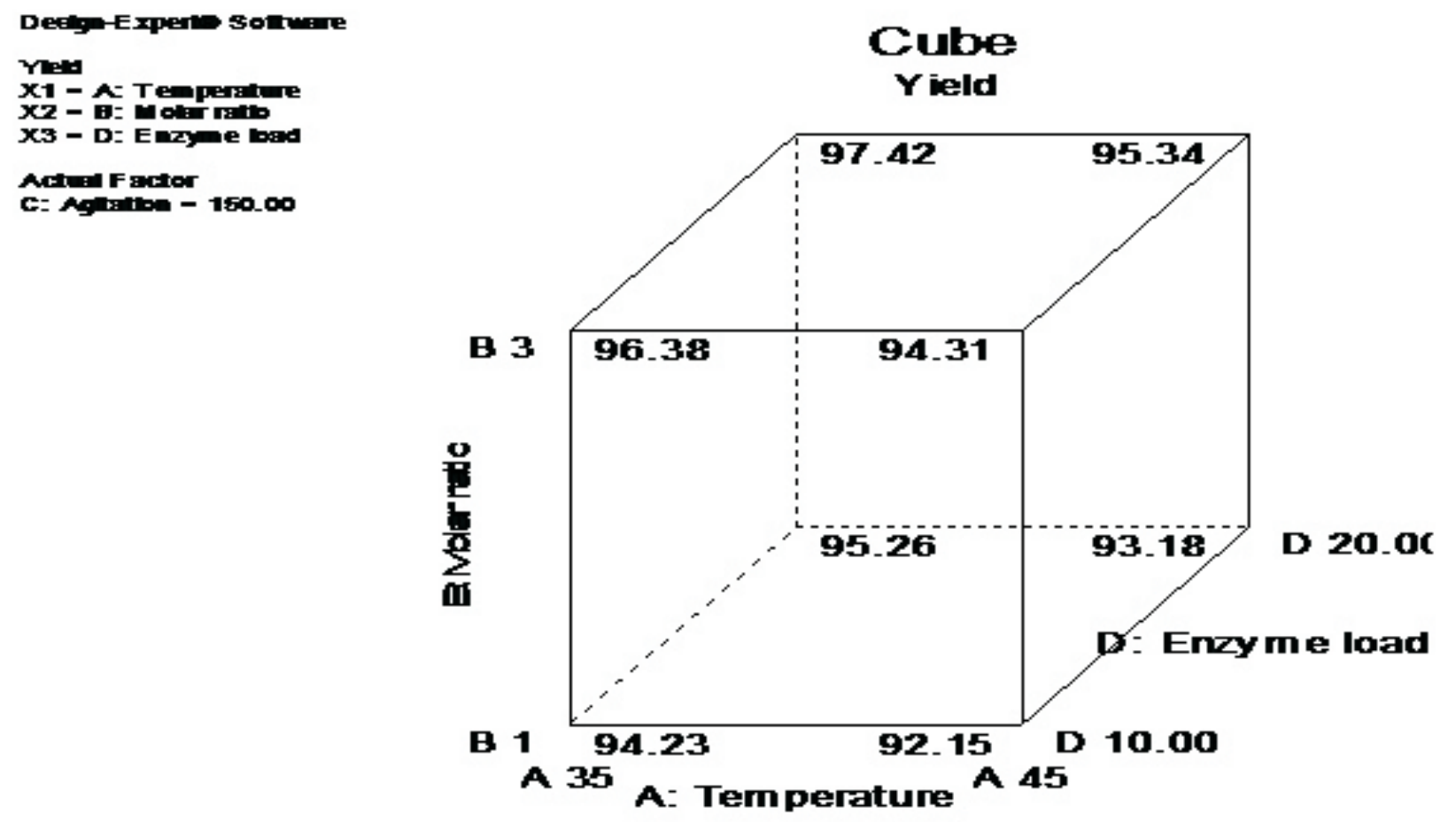

Fig 4: Optimization prediction cube plot for biodiesel yield at varying combined factors

Biodiesel properties including density at $15^{\circ} \mathrm{C}$, kinematic viscosity at $40^{\circ} \mathrm{C}$, flash point, pour point, and cloud point of crude SCO and the produced biodiesel are described in Table 2. The viscosity of SCO biodiesel met the ASTM standard of $6 \mathrm{~mm}^{2} / \mathrm{s}$ maximum, while its density of $893 \mathrm{~kg} / \mathrm{m}^{3}$ at $15^{\circ} \mathrm{C}$ also met the EN standard of $900 \mathrm{~kg} / \mathrm{m}^{3}$ maximum. The flash point and cloud point were also within the limits of both standards.
The summary of chemical composition of samples (Table 3 ) showed that oleic acid is the major fatty acid in the SCO, with $51.87 \%$ composition. Lipase transesterification of SCO however converted it to more Fatty acid methyl esters (FAME) of 9-octadecanoic acid-hydroxyl methyl ester- the compound desired in biodiesels- with composition of about 33\% displayed between retention times of 20.24$20.31 \mathrm{~min}$.

Table 2: Comparison of fuel properties (FAME) of crude Spent Cooking Oil substrate and the produced biodiesel product

\begin{tabular}{lllll}
$\begin{array}{l}\text { Density at } \\
15^{\circ} \mathrm{C}\left(\mathrm{kg} / \mathrm{m}^{3}\right)\end{array}$ & $\begin{array}{l}\text { Flash point } \\
\left({ }^{\circ} \mathrm{C}\right)\end{array}$ & $\begin{array}{l}\text { Cloud point } \\
\left({ }^{\circ} \mathrm{C}\right)\end{array}$ & $\begin{array}{l}\text { Pour point } \\
\left({ }^{\circ} \mathrm{C}\right)\end{array}$ & $\begin{array}{l}\text { Viscosity at } \\
40^{\circ} \mathrm{C}\left(\mathrm{mm}^{2} / \mathrm{s}\right)\end{array}$ \\
\hline 933 & 290 & 6 & 1 & 40 \\
893 & 260 & 3 & -0.5 & 6
\end{tabular}


Table 3: Gas chromatogram analysis of the major composition of crude Spent Cooking Oil substrate and the biodiesel product

\begin{tabular}{lll}
\hline & Retention Time (min) & Compound Composition (\%) \\
\hline Spent Cooking Oil & 19.326 & Oleic acid 16.45 \\
19.566 & Oleic acid 14.34 \\
19.778 & Oleic acid 14.72 \\
20.058 & Oleic acid 6.34 \\
\hline Lipase-produced Biodiesel & 19.600 & Oleic acid 12.91 \\
& 19.829 & Oleic acid 16.50 \\
& 20.241 & Octadecanoic acid methyl ester \\
& 11.87 \\
& 20.310 & Octadecanoic acid methyl ester \\
& & 17.63 \\
& 22.564 & Octadecanoic acid methyl ester
\end{tabular}

\section{Conclusion}

This study showed that biodiesel yield from spent cooking oil can be successfully improved using the Response Surface Methodology (RSM) optimization tool. Fuel properties of produced biodiesel, which is comparable to both ASTM and EU standards, further give credence to this method of optimization. However, further research is needed to improve the yield quality of biodiesel produced.

\section{References}

Abbasi, T., Prmalatha, M. and Abbasi, S. (2011). The return to renewable: Will it help in global warming control? Renew. Sust. Energ. Rev. 15: $891-894$.

Adio, O. Q., Kareem, S. O., Osho, M. B. and Omemu, A. M. (2015). Production of lipases in solid-state fermentation by Aspergillus niger F702 with agricultural residues. J. Microbiol. Biotech. Food Sci. 4 (6): 509 - 512.

Akoh, C. C., Chang, S. W., Lee, G. C. and Shaw, J. F. (2007). Enzymatic Approach to Biodiesel Production. J. Agric. Food. Chem. 55: 277.
Akpan, I. (2004). Screening for novel fungal biocatalyst. Nig. J. Microbiol. 18 (1): 288 - 292.

Demirbas, A. (2003). Biodiesel Fuels from Vegetable oils via Catalytic and Non-Catalytic Supercritical Alcohol Transesterification and other methods: A Survey. J. Energ. Conserv. Manag. 44(13): 2093-2109.

Demirbas, A. (2006). Importance of Biodiesel as Transportation Fuel. Energ. Pol. 35: 4661 - 4670.

Encinar, J. M., Gonales, J. F., Sabio, E. and Ramiro, M. J. (1999). Preparation and properties of biodiesel from Cynara cardunculus L. oil. Ind. Engineer. Chem. Res. 38: 2927 - 2931.

Fan, J., Andre, C. and Xu, C. (2011). A chloroplast pathway for the de novo biosynthesis of triacylglycerol in Chlamydomonas reinhardtii. FEMS Lett. 585: 1985 - 1991.

Hossain, A. B. M. S. and Boyce, A. N. (2009a). Biodiesel production from waste sunflower cooking oil as an environmental recycling process and renewable energy. Bulg. J. Agric. Sci. 15 (4): 313 - 318. 
Hossain, A. B. M. S. and Boyce, A. N. (2009b). Comparative study of biodiesel production from pure palm oil and waste palm oil. Arab. Gulf. J. Sci. Res. 27 (1): 33 - 38.

Janaina, N. P., Juliana, A.B.C. and Gláucia, M. P. (2006). Characterization of Alkaline Lipase from Fusarium Oxysporum and the Effect of different Surfactants and Detergents on the Enzyme Activity.Braz. J. Microbiol. 37: 505 - 509.

Kim, H. J., Kang, B. S., Kim, M. J., Park, Y. M., Kim, D. K., Lee, J. S. and Lee, K. Y. (2004). Transesterification of Vegetable oil to Biodiesel using Heterogeneous Base Catalyst. Catal. Tod. 93-95: 315-320.

Nadir, N., Mel, M., Karim M. I. A. and Yunus, R. M. (2009). Comparison of sweet sorghum and cassava for ethanol production by using Saccharomyces cerevisiae. J. Appl. Sci. 9: 3068 3079.

Orwa, C., Mutua, A., Kindt, R., Jamnadass, R. and Simons, A. (2009). Agroforestry Database: a tree reference and selection guide version 4.0 http://www.worldagroforestry.org/af/treedb/. (Accessed July 15, 2017)

Osho, M. B, Akpan, I. and Kareem, S. O. (2001). Production of amylase by Aspergillus oryzae immobilized in gelatin matrix. Nig. J. Microbiol. 15 (2): $87-91$.

Osho, M. B., Omemu, A. M., Popoola, T. O. S. and Adeleye, T. (2014). Enzymatic Production of Fatty Acid Methyl Ester by Aspergillus niger ATCC 1015 Lipase from Non-Edible Oil. Petrol. Technol. Dev. J. 2: $51-59$.

Owusu, P. A. and Asumadu-Sarkodie, S. (2016). A review of energy sources, sustainability issues and climate change mitigation. Civil. Environ. Engineer. 3: 1167990.

Praphan, P. and Kirk, L. P. (2001). Current Protocols in Food Analytical Chemistry C3.1.1C3.1.13. John Wiley \& Sons. http://dx.doi.org/10.1002/0471142913. fac0301s00

Ribeiro, A., Casro, F. and Carvaiho, J. (2011). Influence of free fatty acid content in biodiesel production on non -edible oils, Wastes: Solutions, Treatments and Opportunities. Proceedings of the first International Conference.

Sarin, A. R., Arora, N. P., Singh, M., Sharma, M. and Malhotra, R. K. (2007). Influence of metal contaminants on oxidation stability of Jatropha biodiesel. Energ. 34 (9): 1271 - 1275.

Vicente, G., Martinez, M. and Aracil, J. (2007). Optimization of Integrated Biodiesel Production. Bioresour. Technol. 98: 1742 - 1733.

Xie, W. and Li, H. (2006). Alumina-Supported Potassium Iodide as a Heterogeneous Catalyst for Biodiesel Production from Soybean oil. J. Mol. Catal. A. 255: 1 - 9.

Taufiq-Yap, Y. H., Abdullah, N. R. and Basri, M. (2011). Biodiesel Production via Transesterification of Palm Oil Using $\mathrm{NaOH} / \mathrm{Al}_{2} \mathrm{O}_{3}$ Catalysts. Sains. Malay. 40 (6): 587-594.

Zhang, W., Bevins, M., Plantz, B., Smith, L. and Meagher, M. (2000). Modeling Pichia pastoris Growth on Methanol and Optimizing the production of a recombinant protein, the heavychain fragment $\mathrm{C}$ of botulinum neurotoxin, serotype A. Biotechnol. Bioeng. 70: 1 - 8. 